\title{
PRODUKTIVITAS PEMELIHARAAN AYAM BROILER DI KAMPUNG BEBANIR BANGUN KECAMATAN SAMBALIUNG
}

\author{
Sri Hartini ${ }^{1 *}$ \\ ${ }^{1}$ Sekolah Tinggi Ilmu Pertanian Berau, Kalimantan Timur, Indonesia \\ "Email: hartinihairudin@gmail.com
}

Diterima: 09 Februari 2021. Disetujui: 04 Maret 2021. Dipublikasikan: 26 April 2021

\begin{abstract}
ABSTRAK
Tujuan penelitian adalah untuk mengetahui Produktivitas pemeliharaan ayam broiler pada usaha peternak ayam broiler dengan pola kemitraan di Kampung Sei Bebanir Bangun Kecamatan Sambaliung Kabupaten Berau. Penelitian ini dilakukan selama 2 bulan, yaitu bulan Oktober hingga bulan Desember 2016. Metode Penelitian adalah deskriptif kuantitatif. Teknik Pengambil Data dengan Purposive Sampling dengan Penentuan Sampel secara sensus. Analisa data dengan Microsoft Excel dan perhitungan secara matematis. Hasil Penelitian memperlihatkan data kepadatan kandang yaitu kepadatan $<10$ ekor $/ \mathrm{m} 2 \pm 10$ ekor $/ \mathrm{m} 2$, dan $>15$ ekor $/ \mathrm{m} 2$. Mortalitas ternak masih Tinggi yaitu Lebih dari $1 \%$, paling rendah yaitu pada Kepadatan \pm 10 ekor $/ \mathrm{m} 2$ yaitu 2,69 ekor/m2. Produksinya pada kepadatan $<10$ ekor $/ \mathrm{m} 2$ dengan bobot rata rata $1,71 \mathrm{~kg}$, pada kepadatan $\pm 10 \mathrm{ekor} / \mathrm{m} 2$ dengan bobot rata rata $1,80 \mathrm{~kg}$, dan pada kepadatan $>15 \mathrm{ekor} / \mathrm{m} 2$ dengan bobot rata rata $1,81 \mathrm{~kg}$. Pada kepadatan $>15 \mathrm{ekor} / \mathrm{m} 2$ lebih efisien dalam pengunaan kandang, namun memiliki mortalitas lebih tinggi dibanding dengan kepadatan $<10 \mathrm{ekor} / \mathrm{m} 2 \pm 10$ ekor $/ \mathrm{m} 2$.
\end{abstract}

Kata Kunci: Produktivitas, Pemeliharaan, Ayam Broiler

\begin{abstract}
The research aims to determine the productivity of broiler chickens' maintenance in broiler breeder business with a partnership pattern in Sei Bebanir Bangun Village, Sambaliung District, Berau Regency. This research was conducted for two months, from October to December 2016. The research method was quantitative descriptive. Data collection techniques with purposive sampling with census sampling. Data analysis using Microsoft Excel and mathematical calculations. The results showed that data on cage density were density $<10$ heads of chicken $/ \mathrm{m} 2, \pm$ 10 head of chicken $/ \mathrm{m} 2$, and $>15$ heads of chicken $/ \mathrm{m} 2$. Chicken mortality is still high, more than $1 \%$, the lowest is at a density of \pm 10 heads of chicken $/ \mathrm{m} 2$, at 2.69 heads of chickens $/ \mathrm{m} 2$. Production at a density of $<10$ heads of chicken $/ \mathrm{m} 2$ with an average weight of $1.71 \mathrm{~kg}$, at a density \pm 10 heads of chickens $/ \mathrm{m} 2$ with an average weight of $1.80 \mathrm{~kg}$, and at a density of $>15 \mathrm{head} / \mathrm{m} 2$ with an average weight of $1.81 \mathrm{~kg}$. At densities $>15$ heads of chicken $/ \mathrm{m} 2$, it is more efficient in using a cage but has higher mortality than those with densities $<10$ heads of chicken $/ \mathrm{m} 2, \pm 10$ heads of chicken $/ \mathrm{m} 2$
\end{abstract}

Keywords: Productivity, Maintenance, Chicken Broiler.

\section{PENDAHULUAN}

Kabupaten Berau merupakan salah satu kabupaten yang berada di propinsi Kalimantan Timur yang letaknya dibagian utara. Luas wilayahnya $34.127,17 \mathrm{~km}^{2}$ yang terdiri dari daratan $21.951,71 \mathrm{~km}^{2}$ dan perairan 11.962,42 $\mathrm{km}^{2}$ dengan jumlah penduduk 179.079 jiwa dengan kepadatan $5,25 \mathrm{jiwa} / \mathrm{km}^{2}$. Secara administratif, Kabupaten Berau terdiri atas 13 Kecamatan, yaitu Tanjung Redeb, Gunung Tabur, Teluk Bayur, Segah, Kelay, Sambaliung, Derawan, Maratua, Tabalar, Biatan, Talisayan, Batu putih dan Bidukbiduk. (BPS Kabupaten Berau, 2017)

Diantara 13 Kecamatan ada 3 kecamatan masyarakat yang paling banyak memelihara ternak ayam Broiler yaitu Kecamatan Sambaliung, Kecamatan Gunung Tabur dan Kecamatan Teluk bayur. Di Kecamatan Sambaliung terkonsentrasi di kampung Bebanir Bangun. Pemeliharaan Ayam Broiler Dikampung Bebanir bangun dengan mengunakan pola kemitraan. Peternak Memilih Pola Kemitraan Karena Peternak menyediaan Kandang dengan Sarana bahwa dalam program kemitraan, peternak cukup menyediakan kandang beserta peralatan dan pekerja, sedangkan sarana produksi seperti Day old chicken(DOC), pakan ternak, vaksin, feed suplement dan obat-obatan disediakan oleh mitra yang biasa merupakan perusahaan besar, dan isi plasma diwajibkan menjual ayam Broiler pedaging. Sedangkan faktor pendorong peternak pola kemitraan adalah: (1) Tersedianya sarana produksi peternak (2) Tersedia tenaga ahli (3)Modal kerja dan (4) Pemasaran terjamin (Yulianti, 2012). 
Populasi ternak ayam pada Tahun 2016 di Kecamatan Sambaliung, yaitu: ayam buras (villagehen) sebanyak18.129 ekor, ayam pedaging (broiler) sebanyak 882.171 ekor dan ayam petelur (layer) sebanyak29.877 ekor. BPS Kabupaten Berau (2017).

\section{METODE PENELITIAN}

Penelitian ini dilaksakan pada bulan Oktober - Desember 2016. Dikampung Bebanir Bangun Kecamatan Sambaliung. Metode yang digunakan dalam penelitian ini adalah deskriptif kuantitatif. Teknik Pengambil Data dengan Purposive Sampling. Penentuan Sampel secara sensus yaitu Peternak yang dijadikan sampel adalah seluruh Peternak yang memelihara Ternak dengan Pola Kemitraan.

Analisis data akan dilakukan dengan membuat tabulasi dengan Microsoft Excel dan perhitunganperhitungan secara matematis berdasarkan hasil jawaban responden.

\section{A. Identitas Responden}

\section{HASIL DAN PEMBAHASAN}

Identitas responden peternak ayam broiler dengan pola kemitraan di Kampung Sei Bebanir Bangun Kecamatan Sambaliung Kabupaten Berau disajikan sebagai berikut :

Tabel 1. Karakteristik Responden Berdasarkan Tingkat Umur

\begin{tabular}{ccc}
\hline Interval Umur (tahun) & Jumlah Peternak (orang) & Persentase (\%) \\
\hline $34-39$ & 8 & 28,6 \\
\hline $40-49$ & 13 & 46,4 \\
\hline $50-59$ & 7 & 25,0 \\
\hline Jumlah & 28 & 100,0 \\
\hline
\end{tabular}

Sumber : Responden Ayam Petelur Pola Kemitraan( 2017).

Umur responden terbanyak di interval 40 - 49 tahun yaitu sebesar 46,4 Persen dan seluruh responden menunjukkan bahwa umur peternak masih berada pada kisaran usia produktif yaitu dibawah 65 tahun, sehingga pihak perusahaan memberikan kepercayaan untuk melakukan kerjasama kemitraan. Ini disebabkan karena umur sangat erat kaitannya dengan penyediaan tenaga kerja yang produktif sebagaimana disimpulkan Herawati dan Sasana (2013) bahwa umur berpengaruh terhadap produktivitas kerja, dimana semakin bertambah umur maka produktivtas kerja cenderung meningkat.

Tabel 2. Karakteristik Responden Berdasarkan Tingkat Pendidikan

\begin{tabular}{ccc}
\hline Tingkat Pendidikan & Jumlah Peternak (orang) & Persentase (\%) \\
\hline SD & 8 & 28,6 \\
\hline SLTP & 7 & 25,0 \\
\hline SLTA & 12 & 42,9 \\
\hline Diploma/Sarjana & 1 & 3,6 \\
\hline Jumlah & 28 & 100,00
\end{tabular}

Sumber : Responden Ayam Petelur Pola Kemitraan( 2017).

Pendidikan Responden bervariatif, Sebagian besar memiliki pendidikan SLTA yaitu sebesar $42,9 \%$, SD sebesar 28,6\%, SMP sebesar 25,0\% dan yang terkecil Diploma/Sarjana sebesar 3,6\%. Pendidikan sebagai bentuk investasi dalam sumber daya manusia kerena memberikan kontribusi langsung terhadap produktifitas kerja melalui peningkatan keahlian, kemampuan dan keterampilan. Pendidikan merupakan bagian penting untuk mendukung usaha yang sedang dijalankan oleh masyarakat sehingga dapat lebih mudah memahami, mengadopsi serta menerapkan teknologi yang sedang berkembang baik dari lingkungannya, pemerintah atau media baik cetak maupun elektronik (Radio atau Televisi). 
AGRIPTEK : Jurnal Agribisnis dan Peternakan

Vol. 1 No.1, April $2021: 18-22$

Tabel 3. Karakteristik Responden Berdasarkan Pengalaman Beternak

\begin{tabular}{cccc}
\hline No. & $\begin{array}{c}\text { Lama Usaha Beternak } \\
\text { (tahun) }\end{array}$ & Jumlah Peternak (orang) & Persentase (\%) \\
\hline 1. & $1-5$ & 9 & 32,2 \\
\hline 2. & $6-10$ & 13 & 46,4 \\
\hline 3. & $>10$ & 6 & 21,4 \\
\hline & Jumlah & 28 & 100,0 \\
\hline
\end{tabular}

Sumber : Responden Ayam Petelur Pola Kemitraan (2017).

Pada usaha peternak ayam broiler dengan pola kemitraan yang memiliki pengalaman diatas 10 tahun sebanyak 21,4\%, terbanyak pada kisaran 6-10 tahun yaitu 46,4\% dan dibawah 5 tahun $32,2 \%$. Pengalaman sangat berpengaruh pada tingkat keahlian dan keterampilan peternak dalam mengelola usahannya, karena semakin lama peternak menjalankan usahanya, maka semakin banyak pula pengalaman yang dimiliki dan semakin baik dalam mengelola usaha peternakannya. Pengalaman beternak merupakan salah satu tolak ukur keberhasilan peternak. Pengalaman akan menunjang peternak dalam mengelola dan menangani ternak yang dipelihara.

Dalam menjalankan usaha pemeliharaan ayam broiler dengan pola kemitraan sebagian peternak menyewa kandang sebagaimana disajikan pada Tabel 4.

Tabel 4. Karakteristik Responden Berdasarkan Status Kepemilikan Kandang

\begin{tabular}{ccc}
\hline Status Kepemilikan & Jumlah Peternak (orang) & Persentase (\%) \\
\hline Milik Sendiri & 23 & 82,1 \\
\hline Sewa & 5 & 17,9 \\
\hline Jumlah & 28 & 100,0 \\
\hline
\end{tabular}

Sumber : Responden Ayam Petelur Pola Kemitraan (2017).

Dalam usaha pemeliharaan ternak ayam broiler Sebagian besar lahan dan kendang yang digunakan untuk kegiatan peternak adalah milik sendiri, yaitu sebesar 82,1\%. Sedangkan status sewa sebesar $17,9 \%$. Ini menunjukkan bahwa semangat masyarakat untuk beternak sangat tinggi.

\section{B. Luas Kandang}

Luas kandang peternak pola kemitraan di Kampung Sei Bebanir Bangun Kecamatan Sambaliung berkisar antara 120-640 $\mathrm{m}^{2}$. lebih rinci luas kandang yang digunakan dalam usaha ternak ayam broiler di Kampung Sei Bebanir Bangun Kecamatan Sambaliung sebagaimana disajikan pada Tabel 5 .

Tabel 5. Karakteristik Responden Berdasarkan Luas Kandang

\begin{tabular}{ccc}
\hline Luas Kandang $\left(\mathbf{m}^{\mathbf{2}}\right)$ & Jumlah (Jiwa) Peternak & Persentase (\%) \\
\hline $100-200$ & 1 & $3,6 \%$ \\
\hline $201-300$ & 4 & $14,3 \%$ \\
\hline $301-400$ & 12 & $42,9 \%$ \\
\hline $401-500$ & 7 & $25,0 \%$ \\
\hline$>500$ & 4 & $14,3 \%$ \\
\hline Jumlah & 28 & 100,0 \\
\hline
\end{tabular}

Sumber : Responden Ayam Petelur Pola Kemitraan (2017).

Kandang ternak yang dimiliki responden peternak terbanyak mempunyai interval luas 301$400 \mathrm{~m}^{2}$ sebesar $42,9 \%$ dan peternak yang memiliki luas kandang dengan interval 100-200 $\mathrm{m}^{2}$ sebesar $3,6 \%$.

\section{Produktivitas Ternak Ayam Broiler Pola Kemitraan}

\section{Mortalitas}

Dalam Pemeliharaan ternak ayam broiler pihak Mitra selalu melihat kapasitas kandang yang dimiliki oleh peternak sehingga produksi ternak ayam broiler selama masa pemeliharaan baik dan menekan angka kematian (mortalitas). Dalam pemeliharaan ternak 
ayam broiler di kampung bebanir bangun bervariasi antara satu peternak dengan peternak lainnya sehingga diperolah rataan dengan kapasitas kurang dari 10 ekor $/ \mathrm{m} 2, \pm 10$ ekor/m2 dan Lebih besar dari 15 ekor/m2. Sebagaimana disajikan pada Tabel 6.

Tabel 6. Kepadatan Kandang dan Persentase Mortalitas ayam broiler

\begin{tabular}{cccc}
\hline Responden & $\begin{array}{c}\text { Rataan Luas } \\
\text { Kandang (m2) }\end{array}$ & $\begin{array}{c}\text { Rataan Kepadatan } \\
\text { Kandang (ekor/m2) }\end{array}$ & $\begin{array}{c}\text { Persentase } \\
\text { Mortalitas }\end{array}$ \\
\hline 6 & 484,50 & 8,36 & $2,99 \%$ \\
\hline 12 & 418,42 & 11,24 & $2,69 \%$ \\
\hline 10 & 282,90 & 16,63 & $3,02 \%$ \\
\hline
\end{tabular}

Sumber : Data Hasil Penelitian Diolah (2017)

Kepadatan kandang pada pemeliharaan ternak ayam broiler di kampung Bebanir Bangun menunjukkan pada bahwa kepadatan kandang kurang dari sepuluh memiliki moralitas yang lebih rendah yaitu 2,99\% dari kepadatan lebih dari 15 ekor/m2 dengan motalitas 3,02\%, namun lebih rendah pada kepadatan normal yang berkisar 10 ekor/m2 dengan motalitas 2,69\% sebagaimana disampaikan Nurfaizin et al. (2014) kepadatan yang terlalu tinggi memiliki efek negatif yaitu peningkatan suhu dan kelembapan dalam kandang serta sirkulasi udara yang buruk sehingga mengakibatkan ayam stress. Sehingga akan berpangaruh terhadap kematian ternak ayam broiler. Angka kematian ternak masih cukup tinggi dari 3 tingkat kepadatan kandang dalam pemeliharaan ayam broiler di Kampung Bebanir Bangun Kec. Sambaliung yaitu masih diatas $1 \%$, maka perlu diperbaiki manajemen pemeliharaan sebagaimana disampaikan Risnajati (2012) bahwa menjalankan manajemen yang baik akan menekan angka kematian.

\section{Produksi}

Upaya dalam untuk memperoleh hasil dengan melihat pertambahan bobot badan ternak dimana Pertambahan bobot badan merupakan kenaikan bobot badan yang dicapai oleh seekor ternak selama periode tertentu. Pada pemeliharaan ayam broiler di Kampung Bebanir Bangun Kecamatan Sambaliung Kabupaten Berau ini memliki tingkat produksi yang berbeda tingkat kepadatan $<10$ ekor/m2, \pm 10 ekor $/ \mathrm{m} 2$ dan $>15$ ekor/m2 sebagaimana disajikan pada Tabel 7.

Tabel 7. Berat Rata-Rata Per Ekor pada Tingkat Kepadatan Tertentu

\begin{tabular}{cccc}
\hline $\begin{array}{c}\text { Kepadatan } \\
\text { Kandang (ekor/m2) }\end{array}$ & $\begin{array}{c}\text { Jumlah Produksi Per } \\
\text { Periode (Kg) }\end{array}$ & $\begin{array}{c}\text { Berat Rata Rata } \\
\text { Per ekor saat } \\
\text { Panen (Kg) }\end{array}$ & $\begin{array}{c}\text { Kepadatan } \\
\text { Kandang } \\
\mathbf{( K g} / \mathbf{m} \mathbf{2})\end{array}$ \\
\hline 8,36 & $6.556,17$ & 1,71 & 14,27 \\
\hline 11,24 & $8.322,83$ & 1,81 & 20,34 \\
\hline 16,63 & $7.782,80$ & 1,80 & 29,97 \\
\hline
\end{tabular}

Sumber : Data Hasil Penelitian Diolah (2017)

Data hasil penelitian menunjukkan bahwa hasil panen pada kepadatan kurang dari 10 ekor/ $\mathrm{m} 2$ memiliki berat rata rata $1,71 \mathrm{Kg} /$ ekor, pada kepadatan \pm 10 ekor $/ \mathrm{m} 2$ memiliki berat rata rata 1,81 dan pada kepadatan $>15 \mathrm{ekor} / \mathrm{m} 2$ memiliki berat rata rata tidak berbeda dengan kepadatan \pm 10 ekor $/ \mathrm{m} 2$ sebesar 1,80 ekor/m2 sebagai mana disampaikan Wijayanti (2011), menyebutkan bahwa kecepatan pertumbuhan dipengaruhi oleh genetik (strain), jenis kelamin, lingkungan, manajemen pemeliharaan, kualitas dan kuantitas pakan yang dikonsumsi. Pada Pemeliharaan Ayam broiler kampung bebanir bangun pada Kepadatan 16,63 ekor menunjukkan bahwa lebih efisien dalam penggunaan kandang tidak jauh beda dengan yang disampaikan Abudabos et al. (2013) yang menggunakan kepadatan 28 $\mathrm{kg} / \mathrm{m} 2,37 \mathrm{~kg} / \mathrm{m} 2$, dan $40 \mathrm{~kg} / \mathrm{m} 2$ pada kandang close house didapatkan hasil bahwa pada kepadatan tinggi yaitu $40 \mathrm{~kg} / \mathrm{m} 2$ konsumsi menurun dibandingkan dengan kepadatan 28 $\mathrm{kg} / \mathrm{m} 2$, dan $37 \mathrm{~kg} / \mathrm{m} 2$. Konsumsi pakan dipengaruhi oleh temperatur lingkungan, kesehatan 
ayam, perkandangan, wadah pakan, kandungan zat makanan dalam pakan dan stres yang terjadi pada ternak unggas tersebut (Faiq et al., 2013). Sedangkan Insani (2010) menyampaikan bahwa rasa nyaman (comfortable) ternak dalam kandang dipengaruhi oleh beberapa faktor, seperti suhu, kelembaban, tingkat kepadatan ternak dan jenis lantai kandang yang dipergunakan. Ayam pedaging yang tidak dapat menampilkan produksinya secara optimal bisa disebabkan karena tidak terserapnya nutrisi pada pakan secara optimal. Dengan penampilan produksi ini sebagaimana disampaikan Sinollah (2011) penampilan produksi berguna untuk evaluasi pada akhir periode dan hasil evaluasi ini berguna untuk membuat keputusan pengisian kembali atau pengosongan kandang.

\section{KESIMPULAN}

Kepadatan kandang pada pemeliharaan ayam broiler di kampung Bebanir Bangun Kecamatan Sambaliung dibagi menjadi 3 yaitu kepadatan $<10$ ekor $/ \mathrm{m} 2, \pm 10$ ekor $/ \mathrm{m} 2$ dan $>15$ ekor $/ \mathrm{m} 2$. Pada tingkat Kepadatan tersebut Motalitas pada Pemeliharaan Ayam Broiler masih Tinggi yaitu Lebih dari $1 \%$, namun dari motalitas paling rendah yaitu pada Kepadatan \pm 10 ekor $/ \mathrm{m} 2$ yaitu 2,69 ekor/ m2. Sedangkan produksinya pada 3 kepadatan tersebut yaitu $<10$ ekor $/ \mathrm{m} 2$ dengan bobot rata rata $1,71 \mathrm{~kg}$, pada kepadatan , \pm 10 ekor $/ \mathrm{m} 2$ dengan bobot rata rata $1,80 \mathrm{~kg}$ dan pada kepadatan $>15 \mathrm{ekor} / \mathrm{m} 2$ dengan bobot rata rata $1,81 \mathrm{~kg}$. Ini menunjukkan bahwa kepadatan $>15 \mathrm{ekor} / \mathrm{m} 2$ lebih efisien dalam pengunaan kandang, namun memiliki mortalitas lebih tinggi dibanding dengan kepadatan $<10$ ekor/m2, \pm 10 ekor $/ \mathrm{m} 2$.

\section{DAFTAR PUSTAKA}

Abudabos, A, M., M. S. Emad, E. O. S. Hussein, M. Q. A. Ghadi and R. M. Atiyat. 2013. Impacts of stocking density on the performance and walfare of broiler chickens. Italian J. Anim. Sci. 12:66-69.

Faiq, U., N. Iriyanti, dan Roesdiyanto. 2013. Penggunaan pakan fungsional dalam ransum terhadap konsumsi pakan dan pertambahan bobot badan ayam broiler. Jurnal Ilmiah Peternakan 1(1): 282-288.

Herawati, N., dan Sasana, H. 2013. Analisis pengaruh pendidikan, upah pengalaman kerja, jenis kelamin dan umur terhadap produktivitas tenaga kerja industri shutllecock Kota Tegal. Diponegoro Journal of Economics, 2(4), 1-8.

Insani, G.A. 2010. Optimalkan Produksi Saat Heat Sterss. Feed Journal Basic.

Nurfaizin, L. D. Mahfudz dan U. Atmomarsono. 2014. Profil hematologi ayam broiler akibat pemeliharaan dengan kepadatan kendang dan penambahan jinta hitam (N. setivai) yang berbeda. Jurnal Agromedia. (1):81-88.

Risnajati, D. 2012. Perbandingan Boot Akhir, Bobot Karkas dan Persentase Karkas Berbagai Strain Broiler. Sains Peternakan vol. 10 (1), maret 2012: 11-14 ISSN 1693-8828.

Sinollah. 2011. Model Pola Kemitraan Usaha Peternakan Ayam Pedaging di Kabupaten Malang. Jurnal Manajemen Agribisnis Vol. 11 no. 3

Yuliantai, F. 2012. Kajian Analisisi Pola Usaha Pengembangan Ayam Broiler. Sociascientia Kopertis Kalimantan, Banjar baru. 